\title{
The Role of Leaders and Community Empowerment in Village Autonomy
}

\section{Mujibur Rohman*), Siti Rodhiyah Dwi Istianah ${ }^{* *}$ and Widayati ${ }^{* * *}$ )}

*) Faculty of Law, Universitas Islam Sultan Agung (UNISSULA) Semarang, E-mail: mujiburrosyid@gmail.com

**) Faculty of Law, Universitas Islam Sultan Agung (UNISSULA) Semarang

***) Faculty of Law, Universitas Islam Sultan Agung (UNISSULA) Semarang

\section{Abstract.}

The research aims to examine (1) What are the duties and authorities of village leaders. (2) How is the implementation of the duties and authorities in community empowerment, and (3) How are the obstacles and implementation solutions in Jetak Village, Wedung District, Demak Regency according to Act No. 6 of 2014. The writing method uses Sociological Juridical qualitatively described as an empirical social phenomenon. The results of the study show (1) that the duties and authorities of village leaders can encourage the realization of village autonomy. (2) Implementation of the duties and authorities of the village head in community empowerment with the management of the Village Owned Enterprise (BUM Des) Jetak Sejahtera with community involvement. (3) Barriers: the courage of village leaders is still lacking, income is not maximized, limited human resources, and community participation that is still lacking awareness. Based on the research, it was concluded that business management training is needed, Cooperating in the management of BUM Des. Prosperous, increasing human resources, increasing community participation in order to implement the principle of transparency in all matters. Community empowerment is a major prerequisite to bring the community towards a dynamic economic, social and ecological sustainability.

Keywords: Autonomy; Community; Empowerment; Village.

\section{Introduction}

The implementation of village government is a subsystem in the national government administration system. So that the village has the authority to regulate and manage the interests of the community (Rodhiyah et al. 2021) ${ }^{1}$. The implementation of village government is regulated in Act No. 6 of 2014 concerning Villages contained in Article 23 that "Village Government is carried out by the Village government."

Government Regulation Number 43 of 2014 concerning Implementing Regulations of Act No. 6 of 2014 concerning Villages Articles 25 and 26 states that: "The Village Head has the task of carrying out government, development and community affairs. Meanwhile, Village Authority includes authority in the field of government administration, appointing and dismissing apparatus, implementing development, holding financial and asset management power, establishing regulations, setting income and expenditure budgets, fostering community life,

1Siti Rodhiyah, "The Choice Problems Of Presidential System In Indonesia Post- Reformation.", in Law Development Journal 4(3) 2021, p. 5. 
fostering peace and order in the village community, fostering and improving the economy based on community initiatives, rights of origin, and customs" 2 .

The duties and authorities of the Village Head are assisted by the village apparatus and the village secretary. In carrying out the duties of the Village Head, the Village Head has the right to propose the organizational structure and work procedures of the Village Government, propose designs and stipulate village regulations. In addition, making village regulations, the village government cooperates with the Village Consultative Body (BPD) to discuss and agree on various policies in the administration of village governance. ${ }^{3}$.

The current position of the village has a very important role in supporting the success of the national government, because the village is a benchmark in the success of the programs planned by the central government. With village autonomy, it is hoped that the village can develop more by being given the authority to take care of its own household ${ }^{4}$, but as a logical consequence of the authority and demands of the implementation of village autonomy is the availability of sufficient funds. So that in order to advance the Village, the Village Government can establish a business entity called a Village Owned Enterprise, the management of which is carried out in the spirit of kinship and mutual cooperation. Village-Owned Enterprises can run businesses in the economic sector and or public services in accordance with the provisions of laws and regulations in the context of empowering communities in the village.

The existence of Act No. 6 of 2014 concerning Villages makes policies regarding villages in providing services, increasing participation and empowerment of rural communities aimed at community welfare, carried out by utilizing local wisdom and village natural resources. This journal discusses how the implementation of the village autonomy law, as an inseparable part of this country, requires a special study in governance.

The research aims to examine (1) What are the duties and authorities of village leaders. (2) How is the implementation of the duties and authorities in community empowerment, and (3) How are the obstacles and implementation solutions in Jetak Village, Wedung District, Demak Regency according to Act No. 6 of 2014.

\section{Research Methods}

The approach method is included in the analytical descriptive research environment with data collection used to obtain accurate and factual data, it is necessary to specify data in the form of primary data and secondary data, namely: Primary Data, by conducting field studies (field research) by means of interviews

\footnotetext{
${ }^{2}$ Optimizing the implementation of Village Government, implementation of Village development, Village community development, and Village community empowerment, it is necessary to stipulate Government Regulations concerning Implementing Regulations of Act No. 6 of 2014 concerning Villages. Sri praptini Siti Kusriyah and Aryani Witasari. "Constitution and Constitutionalism of Indonesia." In Jurnal Daulat Hukum 2(1) p 3.

${ }^{3}$ Ibid.

${ }^{4}$ Muhammad Siddiq Armia. "Hubungan Ideal Partai Politik Dalam Pengisian Jabatan Publik." in jurnal Jurnal Review Politik 07(1) 2017, p 5.
} 
conducted with respondents non-random sampling5. Secondary data, carried out by library research, consists of primary legal materials, namely the Preamble to the 1945 Constitution, laws and regulations, legal materials that are not codified, such as customary law, jurisprudence, treaties and criminal ${ }^{6}$ law books ${ }^{7}$.

Secondary data from primary legal materials in this study are as follows: the 1945 Constitution of the Republic of Indonesia, Act No. 6 of 2014 concerning Villages, Government Regulation No. 43 of 2014 concerning Implementing Regulations of Act No. 6 of 2014 concerning Villages. Secondary data consists of tertiary legal materials in the form of legal dictionary books and relevant encyclopedias that are in accordance with the object of research. The data collection method in the form of taking and determining the sample was chosen to be a respondent using a non-random sampling technique ${ }^{8}$. In line with that the data analysis method is intended for sampling not done randomly but by being selected based on certain considerations that are aligned with the research objectives then reduced, categorized and then concluded.

\section{Results and Discussion}

\subsection{Duties and Authorities of the Village Head as the embodiment of Village Autonomy}

The need for village autonomy is essentially to minimize the intervention of the central government to the village in the administration of a village government that is capable and realizes the will of the community. That increasing the capacity of the Village community by implementing Village Community empowerment can encourage the realization of village autonomy. This can be seen in the implementation of village government which can be interpreted as the obligation of the Village Government to be responsible for the management and implementation of village government that has been carried out to realize village autonomy. 9 .

So that to achieve the goals that have been set through community empowerment activities, the Village community can be held accountable in a measurable manner, both in terms of quality and quantity. The Village Government as the government administrator must be responsible for what has been done (work program) to the community in order to carry out the duties, authorities, and obligations of the Village Government.

\subsection{Implementation of Act No. 6 of 2014 concerning Villages}

\footnotetext{
${ }^{5}$ Muhammad Luthfi, and Hanim Latifah. "Comparative Analysis of Legal Winning Between Islamic Law \& Traditional Law." in Jurnal Daulat Hukum 3(1) 2021, p 7.

${ }^{6}$ A Chuasanga, Ong Argo Victoria. (2019). Legal Principles Under Criminal Law in Indonesia and Thailand, Jurnal Daulat Hukum, Vol $2, \quad$ No 1 (2019) http://jurnal.unissula.ac.id/index.php/RH/article/view/4218

${ }^{7}$ Rodhiyah, Loc. Cit.

8 Ibid.

${ }^{9}$ Ahmad Dahlan. "The Reviewing Concept of Asymmetric Decentralization in The Special Region of Yogyakarta." in Law Development Journal 40(3) 2021, p 2.
} 
BUM Des. management was appointed and inaugurated in early 2019 and only two businesses have been running since the end of $2020 .{ }^{10}$ Businesses that are already running are: Culinary tourism and water management, the rest is used for infrastructure, empowerment, and the Jetak Village government household in an effort to empower the community, which can be seen from three sides, namely:

- Creating a climate or atmosphere that allows the development of community potential (enabling). Every human being has potential that can be developed so that empowerment efforts are aimed at encouraging and raising public awareness of their potential and trying to develop it.

- Strengthening the potential of the community through concrete and more positive steps, such as efforts to increase the level of education and health status as well as opening access to various opportunities that will empower the community.

- Empowering also means protecting, which means that in the empowerment process, the weak must be prevented from becoming weaker. Protection and siding with the weak are very basic in the concept of community empowerment. Protecting must be seen as an effort to prevent unequal competition and exploitation of the weak by the strong. ${ }^{11}$

Several principles or norms relevant to the empowerment process in sustainable development are:

- The principle of responsibility, namely the use of resources that are ecologically sustainable, economically efficient and socially just.

- Decision-making at an appropriate level to promote democratic participation, and decentralization.

- The precautionary principle, namely by providing education and insurance.

- Adaptive management, ie when decisions must be made under conditions of uncertainty, it is necessary to have integrated ecological, social and economic information that is used continuously.

- The principle of participation, namely in the process involving all interests and related parties (stakeholders) with horizontal and vertical relationships. ${ }^{12}$

The village authority includes authority in the field of village government administration, implementation of village development, village community development, and village community empowerment based on community initiatives, origin rights, and village customs. ${ }^{13}$ The management of the potential of natural resources in a sustainable manner is needed to maintain that the benefits of natural resources can be felt continuously in future generations to improve the quality or quality of human life. Thus, the meaning of community empowerment in the realization of Village Autonomy regarding the duties and authorities of the Village Head with Act No. 6 of 2014 concerning Villages has the meaning as a

\footnotetext{
10 Witasari, Loc.Cit.

${ }^{11}$ Widya Putri Idayatama, dan Rakhmat Bowo Suharto. "Economic Integration And Environment In Organizing Ports Services ( Management Of Juridical Analysis Of Tanjung Emas Port In Semarang )." in Jurnal Daulat Hukum 2(2) 2019, p. 4.

${ }^{12}$ Andi Pradikta Alvat. "Politics Of Law Human Rights Protection In Indonesia." dalam jurnal Jurnal Daulat Hukum 2(4) 2019, p. 3.

${ }^{13}$ Rodhiyah, Loc.Cit,
} 
process to increase the ability of individuals or communities which is carried out democratically so that they are able to build themselves and their environment so that they are able to live independent and prosperous ${ }^{14}$.

\subsection{Barriers and Solutions to the Implementation of Act No. 6 of 2014 concerning Villages}

The results of this study can be concluded that, the existence of Village Autonomy with the issuance of Act No. 6 of 2014 concerning Villages is currently an important problem that must be fought for by the village in the implementation of its autonomy of authority. Fiscal decentralization, as well as the duties and authorities of the Village Head, should be carried out to the maximum, because the village is an autonomous region. In contrast to the village which is still an extension of the sub-district, the village has autonomous authority in the implementation of its government. The problem is, fiscal decentralization in village autonomy has not running optimally because it still requires adjustments to the village government ${ }^{15}$.

\section{Clossing}

Improve the ability to administer government in an empowered manner. Meanwhile, the need for village autonomy is essentially to minimize the intervention of the central government to the village in the administration of a village government that is capable and realizes the will of the community. Implementation of Act No. 6 of 2014 concerning Villages on the Duties and Authorities of the Village Head in empowering Village communities as the presence of village autonomy, where the village organizes government independently. The results of the study show (1) that the duties and authorities of village leaders can encourage the realization of village autonomy. (2) Implementation of the duties and authorities of the village head in community empowerment with the management of the Village Owned Enterprise (BUM Des.) Jetak Sejahtera with community involvement. (3) Barriers: the courage of village leaders is still lacking, income is not maximized, limited human resources, and community participation is still lacking awareness. The obstacles and solutions to implementation are the Head of Jetak Village, Wedung District, Demak Regency, who has not dared to take policies formulated for village development, income from the management of $B U M$ Des. has not been maximized, limited Human Resources (HR) in managing BUM Des., community participation is still lacking awareness of the policy of the Jetak Village Head. Then the solutions were carried out: Conducting a kind of training on how to manage a business well, cooperating in the management of BUM Des. Jetak Sejahtera, increasing human resources for BUM Des., increasing community participation in order to implement the principle of management transparency.

${ }^{14}$ Djunaedi, Loc. Cit.

${ }^{15}$ Lathifah, Loc. Cit. 


\section{References}

\section{Journals}

[1] A Chuasanga, Ong Argo Victoria. (2019). Legal Principles Under Criminal Law in Indonesia and Thailand, Jurnal Daulat Hukum, Vol 2, No 1 (2019) http://jurnal.unissula.ac.id/index.php/RH/article/view/4218

[2] Alvat, Andi Pradikta. 2019. "Politics Of Law Human Rights Protection In Indonesia." Jurnal Daulat Hukum 2(4): 513-20.

[3] Dahlan, Ahmad. 2021. "The Reviewing Concept of Asymmetric Decentralization in The Special Region of Yogyakarta." Law Development Journal 40(3): 120-23.

[4] Djunaedi, D. 2021. "Juridical Analysis Related To Confidentiality Of Notary Liability." Law Development Journal 4(1): 91-99.

[5] Idayatama, Widya Putri, and Rakhmat Bowo Suharto. 2019. "Economic Integration And Environment In Organizing Ports Services (Management of Juridical Analysis Of Tanjung Emas Port In Semarang )." Jurnal Daulat Hukum 2(2): 293-98.

[6] Luthfi, Muhammad, and Lathifah Hanim. 2021. "Comparative Analysis of Legal Winning Between Islamic Law \& Traditional Law." Jurnal Daulat Hukum 3(1): 61-70.

[7] Muhammad siddiq armia. 2017. "Hubungan Ideal Partai Politik Dalam Pengisian Jabatan Publik." Jurnal Review Politik 07(1): 126-46.

[8] Praptini, Sri, Sri Kusriyah, and Aryani Witasari. 2019. "Constitution and Constitutionalism of Indonesia." Jurnal Daulat Hukum 2(1): 7-14.

[9] Pratomo, Ardito Yudho, Umar Ma, and Aryani Witasari. 2021. "Implementation of Criminal Action Prosecution Online in Realizing Principle of Fast Prosecution , Simple \& Low Cost." Law Development Journal 14(2): 132-39.

[10] Regency, Demak et al. 2020. "Implementation of Local Regulations Concerning Market Charges and Problems in Practice." Jurnal Daulat Hukum 2(32): 1-10.

[11] Rodhiyah, Siti et al. 2021. "The Choice Problems Of Presidential System In Indonesia Post- Reformation." Law Development Journal 4(3): 208-21. 